UDC 811.161.1'36

https://doi.org/10.18485/ms zmsfil.2020.63.2.7

Изворни научни рад

\title{
Радослава Трнавац
}

\section{ИЗРАЖАВАЮЕ АУТОРСКОГ СТАВА У УВОДНИЦИМА И ОНЛАЈН КОМЕНТАРИМА НА РУСКОМ ЈЕЗИКУ}

\begin{abstract}
Базирајући се на методологији Бајбера (ВівER 2006), рад се бави упоредном анализом учесталости употребе групе граматичких структура које изражавају ауторски став на руском језику у уводницима и онлајн коментарима вести. Анализа показује да је фокус унутар уводника пре свега на позицији аутора којом се карактерише нека радња, а у нешто мањој мери на говорним чиновима и на антиципаторном аспекту текста, док је фокус у онлајн коментарима најпре на епистемичкој и директивној димензији ауторског става.

Кључне речи: ауторски став, регистар, корпусна анализа, граматичке структуре.

Based on the methodology of Biber (BIBER 2006), this paper deals with a comparative analysis of the use of the grammatical structures that express stance in editorials and online news comments in Russian. The analysis shows that the focus of editorials is on the author's perspective that characterizes certain actions or events, and to a lesser extent on speech act verbs and on anticipatory aspects of texts, while the focus of online comments is on the epistemic and directive dimensions of stance.
\end{abstract}

Key words: stance, register, corpus analysis, grammatical structures.

1. Увод. У овом раду ћемо се бавити компарацијом фреквентности употребе граматичких облика који изражавају ауторски став на руском језику у уводницима дневног листа Независимаја і $а з е \bar{и} а$ из 2020. године и у онлајн коментарима вести из 2019. године постављеним на сајту информативног медија на руском језику $P T$. Циљ рада представља контрастирање групе граматичких средстава која изражавају ауторски став у два поменута регистра (подврсте текста), као и издвајање потенцијално дистинктивних језичких образаца за карактеризацију евалуације у њима. Рад се неће бавити детаљном семантичком и синтаксичком анализом самих средстава, већ је фокус на квантитативној анализи тих средстава у наведеним корпусима, као и на семантичкој вредности коју они својим присуством креирају у текстовима.

Према дефиницији Бајбера и Конрадове (BIBER - CONRAD 2019: 6), регистар представља подврсту текста која се асоцира са одређеном ситуацијом употребе (укључујући одређене комуникативне циљеве). Опис једног регистра укључује три главне компоненте: ситуациони контекст, лингвистичке карактеристике и функционалне односе између прве две компоненте. Регистри могу бити више или мање специјализовани. На пример, како се илуструје у делу Бајбера и Конрадове (BIBER - CONRAD 2019: 32), један од најопштијих говорних регистара је конверзација која укључује неколико карактеристика: два или више учесника који имају међусобну интеракцију усменим путем. С друге стране, разговор преко телефона представља специјализованији тип конверзације јер учесници морају да комуницирају електронским путем и не деле исти физички простор. У овом делу рада ћемо укратко поменути и 
дефиницију жанровске анализе текста на начин како њу дефинише Бајбер јер би се читаоцу могло учинити да анализа регистра потпада под жанровску анализу. Према дефиницији Бајбера и Конрадове (BIBER - CONRAD 2019: 16), жанровска анализа текста се обично фокусира на језичке карактеристике које се појављују само једном у тексту. Ове карактеристике имају главну улогу у томе како се конструише одређени текст. Оне су конвенционалним путем повезане са жанром о коме се говори и подвргавају се културолошким захтевима за конструисање текстова истог типа које читалац тих текстова има. Жанровска перспектива дискурса се, према дефиницији Бајбера и Конрадове, обично фокусира и на реторичку организацију у тексту. Наш рад се неће бавити том анализом, па сам термин неће бити коришћен у њему.

Дакле, проучавање регистра комбинује анализу језичких карактеристика које су учестале у одређеној подврсти текста са анализом комуникативне ситуације коришћења дате подврсте текста. Главна хипотеза сваке анализе одређеног регистра је да основне групе језичких црта, као на пример појава глагола и придева, служе неким комуникативним циљевима. Као резултат тога, поједине језичке карактеристике су честе у регистру јер су функционално адаптиране комуникативним вредностима и ситуационим контекстима текстова из датог регистра. Циљ овог рада би било и издвајање комуникативних функција које одређена евалуативна средства имају у два регистра. Поређење поменутих регистара до сада, колико је нама познато, по датом принципу није било спроведено у научној литератури.

У последњих тридесетак година лингвисти су се интезивно бавили питањима језичких механизама које говорници или аутори писане речи користе да би изразили своју позицију, суд, оцену или емоције. Ми ћемо овде укратко издвојити неколико најпопуларнијих праваца, насталих у оквиру лингвистичке традиције на енглеском језику која интензивно проучава феномен изражавања ауторског става у дискурсу, између осталог, и због потреба рачунарске лингвистике, односно развоја аутоматске обраде текста ${ }^{1}$. Истраживања у области анализе евалуације у тексту укључују различите домене, од којих су најпознатија радови на пољу евалуације (HUNSTON - THOMPSON 2000; MARTIN - White 2005), евидентности (ChAFE - Nichols, 1986), афекта (ОснS SCIEFFelin 1989) и ауторског става (BiBER - FinEgAn 1989; ConRAD - BibER 2000)2.

Једно од првих системских истраживања у области изражавања ауторске позиције је представљено у радовима Бајбера и Финегана (BIBER - FINEGAN $1988 ; 1989)$, који су проучавали улогу адвербијала, прилога и придева на примерима различитих корпуса ${ }^{3}$. Поменути аутори су дате маркере сврстали у одвојене категорије, базирајући се на дистинктивним семантичким и граматичким критеријумима маркера, као и на њиховој карактеристици да учествују у диференцијацији дискурсивних стилова. Конрадова и Бајбер

${ }^{1}$ Ради се о тзв. анализи става/становишта (на енглеском је термин sentiment analysis) која ce, између осталог, бави аутоматском анализом ауторске позиције о неким производима, филмовима, књигама, техничким предметима, итд. Видети, на пример, истраживање TABOADA et al. 2011.

2 Овај рад нема за циљ исцрпно представљање литературе о евалуацији.

${ }^{3}$ На руском језику питањима евалуације се бавиио Виктор Иванович Шаховски (2008). У српској литератури треба обратити пажњу на монографије ДРАГићЕвић 2001 и ТрнАВАц 2018. 
(CONRAD - BIBER 2000) су се бавили изучавањем адвербијалних маркера приликом изражавања ауторске позиције у различитим усменим и писаним регистрима. Језички обрасци су затим били интерпретирани функционално у односу на комуникативне карактеристике сваког регистра. Према закључку из датог рада епистемичка позиција аутора је ретко била сигнализирана у новинским репортажама, али неколико различитих типова епистемичке позиције адвербијала могло се идентификовати у академској прози на енглеском језику4.

Онлајн коментари постају предмет лингвистичке анализе крајем 90 -их година у Сједињеним Америчким Државама да би се касније ова тематика проширила и на европско тло (WeIZMAN - DoRI-HACOBEN 2017). Фокус радова из ове области је на негативним језичким феноменима. Поменућемо овом приликом једну честу тему, а то је језик антагонизма, конфликта и дискриминације у оквиру онлајн коментара (ĐoRĐEVIĆ 2020; LANGLOTZ - LOCHER 2012; СидоРовА 2014 и др. $)^{5}$. Према подацима наведеним у раду Ехретове и Табоаде (ЕHRET - TABOADA 2020), онлајн коментари вести представљају мање истражену област него онлајн коментари у оквиру различитих друштвених мрежа и форума. Излажући преглед литературе везане за лингвистичке анализе онлајн коментара вести на енглеском језику, аутори истичу да је најранија публикација био рад Бруса (BRUCE 2010), где су коментари карактеризовани као субјективни и као они који се обично односе на садржај презентован у чланку или на други коментар који је претходно постављен. Језик ауторског става у онлајн коментарима вести на енглеском и на руском језику анализиран је у раду Трнавац и Табоаде (TRNAVAC - TABOADA, у припреми) уз примену методолошког оквира функционално-системске лингвистике унутар теорије оцене Мартина и Bajтa (MARTIN - WhITE 2005). Што се тиче језика уводника, он је био релативно честа тема радова који се баве анализом евалуације у дискурсу. У овом делу ћемо само навести монографију ТРнАвАц 2018, у којој је спроведена контрастивна корпусна анализа ради проучавања односа између реторичке структуре текста и евалуативног језика на материјалу уводника на српском и на руском језику.

Досадашњи аспект проучавања евалуативног језика проширићемо у овом раду контрастивним приступом, упоређујући изражавање ауторског става у два различита регистра: у уводницима и онлајн коментарима вести да бисмо закључили постоји ли разлика између њих која је условљена степеном појаве граматичких облика у евалуативној функцији. На дату тематику применићемо методологију проучавања ауторског става коју је утемељио Бајбер (ВIвER 2006) у анализи говорних и писаних универзитетских регистара $^{6}$, следећи методе истраживања Бајбера и др. (BIBER et al. 1999), које су

\footnotetext{
${ }^{4}$ Детаљније о литератури о евалуацији на енглеском језику в. у: TRNAVAC - TABOADA (y припреми).

5 Детаљнију информацију о различитим лингвистичким анализама онлајн коментара погледати у радовима ЕHRET - TABOADA 2020 и TRNAVAC - TABOADA (у припреми).

${ }^{6}$ Под усменим универзитетским регистрима се подразумев, на пример, настава спроведена у учионицама, као и усмене консултације са студентима, док писани универзитетски регистри укључују различите видове студентских радова који су саставни део универзитетске наставе.
} 
настале приликом рада на великим корпусима ради креирања Лонгманове граматике усменог и писаног енглеског језика. Бајбер (BIBER 2006) је, наиме, у раду о усменим и писаним универзитетским регистрима издвојио четири групе језичких средстава које су интересантне из перспективе проучавања начина на који граматичке структуре креирају евалуацију у тексту․․ На основу поменутог рада у нашем корпусу ћемо истраживати фреквентност појаве следећих граматичких облика прилагођених структури руског језика:

- модалних форми за изражавање могућности/способности, неопходности/обавезе, предикције/воље (могу 'могу', я должен, ‘ја треба да', я буду 'ja hy');

- прилога за изражавање епистемичке извесности, вероватноће, става, начина или перспективе (конечно 'наравно', на самом деле 'у ствари', очевидно 'очигледно', может быть 'можда', удивительно 'неочекивано', важно 'важно', в общем-то 'уопште');

- глагола за изражавање епистемичке извесности, вероватноће, става, модалитета говорног чина, когнитивних радњи, жеље/интенције/одлуке (думать 'мислити', надеяться 'надати се', сомневаться 'сумњати', сказать 'рећи', считать 'сматрати');

- придева за изражавање евалуације (существенный 'важан', важный 'важан') ${ }^{8}$.

У другом одељку овог рада представићемо подробније примере за сваку од наведених категорија, чиме ћемо детаљније илустровати приступ евалуацији у дискурсу Бајбера и његових колега. Треће поглавље пружа кратку дескрипцију корпуса и софтвера које смо користили приликом анализе текста. Четврто поглавље излаже резултате наше анализе, као и дискусију у вези са њом, док пето поглавље презентује закључак рада.

2. МоДЕЛ ЗА ИНТЕРПРЕТАЦИЈУ ПРИМЕРА. Језичка средства моГУ бити коришћена да би изразила емоције, ставове, системе вредности, што потпада под шири појам евалуације. Фокус овог рада представља изабрани скуп експлицитних граматичких структура које се користе да изразе став аутора у односу на неку другу исказану пропозицију. Од сваке од наведених категорија које су анализиране у смислу учесталости употребе у нашем корпусу, а које су наведене у претходном поглављу, издвојићемо по један пример 9 . Као посебну напомену ћемо издвојити да већина представљених граматичких структура захтева комбинацију са везником что 'да' или са инфинитивом. Илустрацију тих структура ћемо започети примерима из домена модалности.

- Модални облици за изражавање могућности/способности (+ инфинитив):

${ }^{7}$ Издвојене граматичке структуре су значајне за проучавање евалуације у већем броју европских језика, не само у енглеском језику.

${ }^{8}$ Евалуативну улогу у руском језику би, свакако, играле и поједине групе дугих и кратких облика партиципа, али имајући у виду граматичке категорије описане у раду Бајбера (BIBER 2006), у оквиру којих није било партиципа, ове облике нисмо укључивали у наше истраживање.

9 Уколико није назначен други извор, наведени примери су преузети из нашег корпуса. 
(1) У них редко можно обнаружить идеологическую привязанность к какой-либо партии.

'Код њих се ретко може наћи идеолошка пристрасност према некој од партија.'

- Модални облици за изражавање неопходности/обавезе:

(2) К примеру, в Общенациональном плане восстановления экономики, так же как и раньше, ставка делается на инфраструктурные проекты, и они необязательно должны быть новыми.

'На пример, у националном програму за обнову економије се, исто као и раније, ставља акценат на пројекте везане за инфраструктуру, који не морају бити нови.'

- Модални облици за изражавање предикције/воље:

(3) Примечательно, что восстанавливать экономику теперь будут с использованием тех же механизмов, которыми совсем недавно намеревались ее ускорять. 'Запажа се да ће обнову економије спроводити уз употребу истих механизама које су имали намеру недавно да користе ради утицања на економско убрзање.'

- Прилози за изражавање епистемичке извесности (+ везник что)

(4) Понятно, что скорее всего в ходе общероссийского голосования никаких манипуляций с ДЭГ не будет, исходя из той же политической целесообразности. 'Јасно је да највероватније током сверуског гласања неће бити никаквих манипулација са електронским гласањем уколико се поступа на основу истоветне политичке сврсисходности.'

- Прилози за изражавање епистемичке вероватноће (+ везник что)

(5) Вероятно, (что) унификации своих позиций по поводу роли Китая в пандемии Трамп будет решительно добиваться от союзников как в Европе, так и на Ближнем Востоке.

'Вероватно ће хомогенизацију позиција поводом улоге Кине током пандемије Трамп одлучно тражити од савезника, како оних у Европи, тако и оних на Блиском истоку.'

- Прилози за изражавање става (+ везник что)

(6) Вполне очевидно, что за ним будущее, и пандемия лишь ускоряет его приближение.

'Сасвим је очигледно да он има будућност и да пандемија само још убрзава његово приближавање.’

- Прилози за изражавање начина или перспективе

(7) $B$ частности, из-за пандемии была приостановлена полноценная реализация «пакета Яровой».

'Управо је због пандемије заустављена комплетна реализација пројекта „Јаровој".'

- Глаголи за изражавање епистемичке извесности

(8) Запланированные деньги выделяются, они должны быть потрачены по соответствующим статьям, то есть так или иначе деятельность учреждения должна осуществляться, а значит - должны платиться зарплаты. 
'Планирани новац се издваја и мора бити употребљен према одговарајућим правилима, односно, било како, делатност институције се мора спроводити, а то значи да се морају исплаћивати зараде.'

- Глаголи за изражавање епистемичке вероватноће (+ везник что)

(9) Предполагается, что деньги пойдут на первоочередные нужды - зарплату, оплату коммунальных услуг, содержание имущества.

'Претпоставља се да ће новац ићи на приоритете - зараду, плаћање комуналних услуга, одржавање имовине.'

- Глаголи за изражавање става

(10) Надеюсь, не совсем.

'Надам се да не (треба) у потпуности.'

- Глаголи за изражавање говорног чина (+ везник что)

(11) В статье 13 Конституции РФ говорится, что никакая идеология не может устанавливаться в стране в качестве государственной и обязательной.

'У члану 13 Устава Руске Федерације се каже да никаква идеологија не може да се намеће у земљи као државна и обавезна.'

- Глаголи за изражавање когнитивних радњи (+ везник что)

(12) Вспомним, что прокремлевское движение «Наши» в свое время получало деньги на свои проекты...

“Сетимо се да је покрет „Наши” који подржава Кремљ у своје време добио новац за своје пројекте ...'

- Глаголи за изражавање жеље/интенције/одлуке (+ инфинитив)

(13) Я хочу прочитать эту статью ${ }^{10}$. 'Желим да прочитам овај чланак.'

- Придеви за изражавање евалуације (+ инфинитив)

(14) Нелегко найти людей, особенно среди нового поколения, не жившего в СССР, zomoвblx воспринимать политическую жизнь как борьбу «доброго» социалистического начала со «злым» капиталистическим и воплощением последнего считать правящую элиту.

'Није лако наћи људе, посебно међу новим поколењем које није живело у Совјетском Савезу, који су спремни да прихвате политички живот као борбу „доброг” социјалистичког са „злим” капиталистичким начелом и да сматрају отелотворењем последњег владајућу елиту.'

3. АНотАцијА коРПуСА. Материјал који смо анализирали у оквиру онлајн коментара вести за 2019. годину потиче из медијске куће $P T$, руске интернационалне телевизијске мреже која пружа услуге емитовања телевизијских канала публици ван граница Руске Федерације и која емитује интернет садржај на енглеском, шпанском, француском, немачком, арапском и руском језику. Фокус вести чије коментаре смо обрађивали представљају политика, информационе технологије и социјална проблематика. Што се тиче корпуса уводника, изабрали смо 9 текстова са краја маја и почетка јуна месеца 2020.

${ }^{10}$ Пример није пронађен у нашем корпусу, већ је конструисан. 
године из области политике. Оба корпуса имају по 10.000 речи. С обзиром на то да се ради о малим корпусима, њихову анотацију је спровела ауторка рада самостално, што гарантује конзистентност анализе. Сваки текст у корпусу је био анализиран два пута у различитим временским интервалима. Анотације су у случају коментара спроведене над сваким индивидуалним коментаром који је био подељен у засебне реченице, док је у уводницима исто тако извршена анализа сваке реченице. За анотацију смо користили УАМ coфтвер (O’DONNELL 2008). Дати софтвер омогућује анотацију многобројних текстова уз коришћење исте анотацијске схеме коју креира сам аутор анотације. Анотација сваког текста обично се обавља хијерархијски, у неколико нивоа, а софтвер обезбеђује и обављање компаративне статистике за потребе аутора између различитих поткорпуса ${ }^{11}$. Ради прегледнијег увида у хијерархијски систем који је коришћен приликом анализе прилажемо слику наше анотацијске схеме.

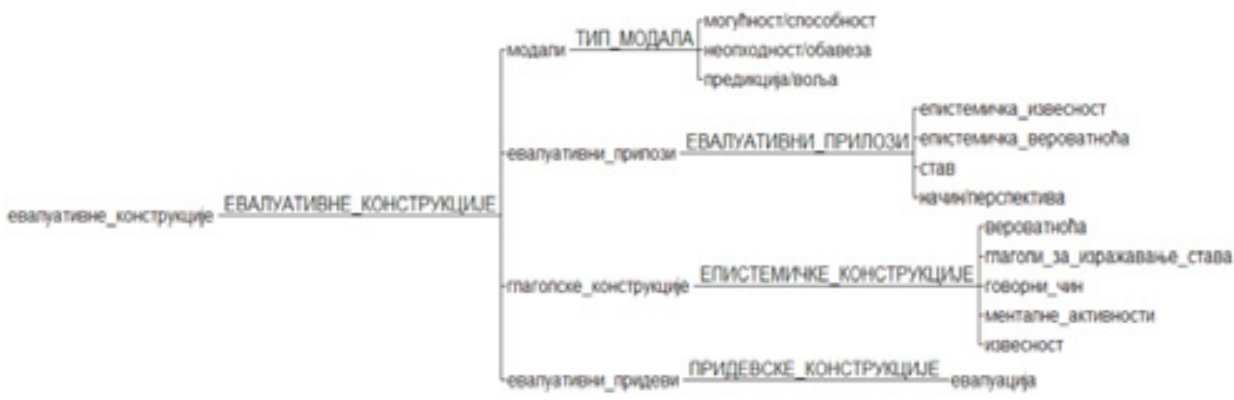

Слика 1. Анотацијска схема примењена на корпус уводника и онлајн коментара

4. РЕзУЛтАти АНАЛИзЕ. У овом поглављу ћемо прво у оквиру табеле представити опште резултате анализе свих наведених граматичких облика и њихових поткатегорија у два регистра, у уводницима и у онлајн коментарима, што представља главни, квантитавни део рада. Паралелно са тим ћемо представити квалитативну анализу у којој ћемо повезати резултате везане за лингвистичке карактеристике са комуникативном и функционалном употребом у датој подврсти текста.

Табела 1. Граматички облици у функцији изражавања ауторског става у уводницима и онлајн коментарима

\begin{tabular}{|l|c|c|}
\hline \multicolumn{1}{|c|}{ Граматички облици } & Подаци за уводнике & Подаци за онлајн коментаре \\
\hline Модални облици & 112 & 156 \\
\hline Прилози & 99 & 8 \\
\hline Глаголи & 91 & 12 \\
\hline Придеви & 4 & 2 \\
\hline Укупан број & $\mathbf{3 0 6}$ & $\mathbf{1 7 8}$ \\
\hline
\end{tabular}

${ }^{11}$ УАМ софтвер је могуће бесплатно преузети на следећем сајту: $<$ http://www.corpustool. com> 
Из табеле 1 се може запазити да и један и други регистар имају највише модалних форми. Драстична разлика је присутна када је реч о прилошким и придевским конструкцијама са значењима истакнутим у првом поглављу. Њихов број је значајнији у уводницима него у онлајн коментарима. Уопштено говорећи, укупан број издвојених граматичких форми за изражавање ауторског става је већи у уводницима него у онлајн коментарима, што наводи на закључак да је присуство субјекта, аутора текста, експлицитније изражено у поменутом регистру. Иако су Ехретова и Табоада (ЕнRET - TABOADA 2020) показале на корпусу енглеског језика да су онлајн коментари заправо ближи уводницима по употреби облика који садрже експлицитно изражено мишљење, односно аргументативни, евалуативни дискурс него спонтаној конверзацији са којом се обично у литератури пореде онлајн коментари, наши резултати на малом корпусу руског језика показују да је експлицитно мишљење у обилнијој мери исказано у уводницима.

На основу података приказаних у следећим дијаграмима, рамотрићемо поткатегорије облика из табеле 1 , те утврдити која је њихова функција у тексту.

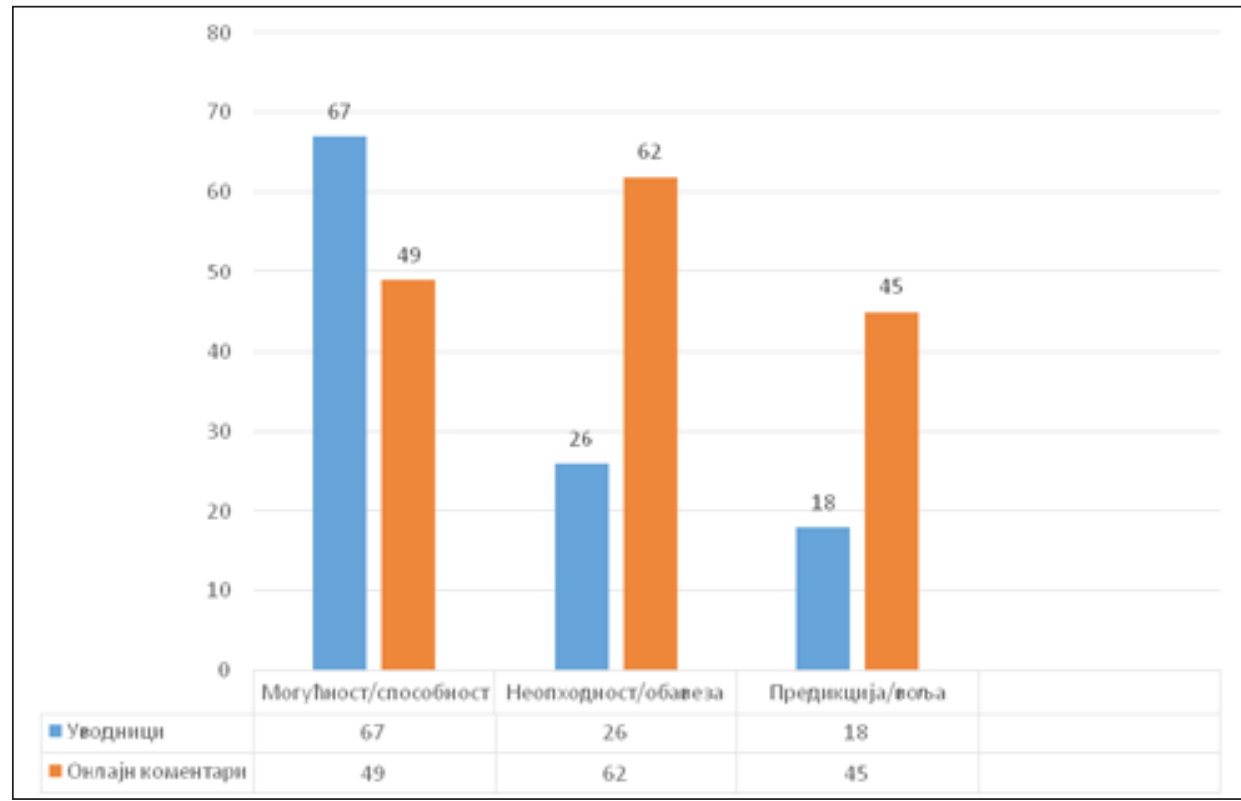

Дијаграм 1. Заступљеност категорије модалности у корпусу уводника и онлајн коментара на 10.000 речи

У складу са већ изнетом опсервацијом, категорија модалности је најзаступљенија међу одабраним граматичким облицима у оба регистра. Та категорија је за нијансу фреквентнија у онлајн коментарима него у уводницима (156 према 112). Такође, модални облици за изражавање предикције/воље су најмање заступљена класа модала у обе врсте текста, иако су они далеко присутнији у онлајн коментарима него у уводницима (45 према 18). У оба 
регистра се у преко 90\% инстанци ради о облицима која изражавају искључиво планове за будуће догађаје. Исто тако, дијаграм 1 показује да постоје разлике у коришћењу других модалних категорија између два регистра. Облици за изражавање могућности су фреквентнији у уводницима него у онлајн коментарима (67 према 49), док су у онлајн коментарима фреквентније форме којима се исказује неопходност и та разлика у заступљености између два регистра је драстична (62 према 26).

Модални облици за исказивање могућности у обе врсте текстова исказују пре свега значење епистемичке вероватноће, а у далеко мањем степену способност субјекта да изврши неку радњу. Најфрекветнији је облик глагола у 3. лицу садашњег времена может 'може'. Дати глагол може указивати и на епистемичку вероватноћу, као и на способност за обављање неке радње. Модални облик возможно 'могуће' се такође користи у исте сврхе:

(15) ...это может говорить о том, что девочку насильно отобрали по каким то там причинам...

'ово може да говори о томе да су девојчицу на силу узели из неког тамо разлога...’

(16) Французский премьер Эдуар Филипп на встрече с российским коллегой Дмитрием Медведевым заявил, что Евросоюз может̄ отменить антироссийские санкции.

'Француски премијер Едуард Филип је приликом сусрета са руским колегом Димитријем Медведовим изјавио да Европска унија може (има капацитет) да укине антируске санкције.'

(17) Это возможно лишь в случае решения проблемы ПРО, к которому не приступает Путин...'

То је могуће само у случају решавања проблема противваздушне одбране, чему Путин још не приступа...'

(18) ...возможно есть следы и сексуального насилия....

'...могуће је да постоје трагови и сексуалног насиља... '

Реченице (15) и (18) указују на епистемичку вероватноћу, док (16) и (17) на капацитете субјекта да реализују одређене активности.

Као што је било раније поменуто, модални облици за изражавање неопходности су чешћи у онлајн коментарима. Присутне су форме како за изражавање прескриптивне функције или деонтичке модалности која се односи на правила и норме како се треба понашати у одређеној ситуацији, тако и облици у функцији исказивања персоналне обавезе:

(19) ...нужно всего лишь придумать провокацию посерьёзней и санкции придётся ввести...

'Потребно је само измислити озбиљнију провокацију и санкције ће бити уведене...’

(20) ...в Ингушетию не надо возвращать (ребенка)...

'У Ингушетију не треба враћати (дете)...'

(21) С себя и должен начать Путин.

'Од себе и треба да почне Путин.' 
У примерима (19) и (20) је илустрована прескриптивна улога модалних речи која се односи на неку ситуацију, док се у примеру (21) изражава персонална обавеза субјекта. Облик должен којим се чешће исказује персонална обавеза има израженије значење неопходности, него облици за маркирање деонтичке модалности који укључују генерална правила, норме или савете како поступити у одређеној ситуацији. Сходно општем тренду везаном за исказивање модалности у оба регистра, дати модални облик је чешћи у онлајн коментарима. Као закључак о модалима можемо рећи да је њихова функција у онлајн коментарима пре свега да се назначи како би ствари требало да буду, односно функционишу, док уводници садрже модале антиципаторне природе који се фокусирају на потенцијале за реализацију неке активности.

Следећа категорија су прилози за изражавање епистемичке извесности, вероватноће, става, начина или перспективе. Њих налазимо у драстично већем броју у оквиру уводника. Дијаграм 2 представља дистрибуцију прилога у зависности од врсте којој припадају:

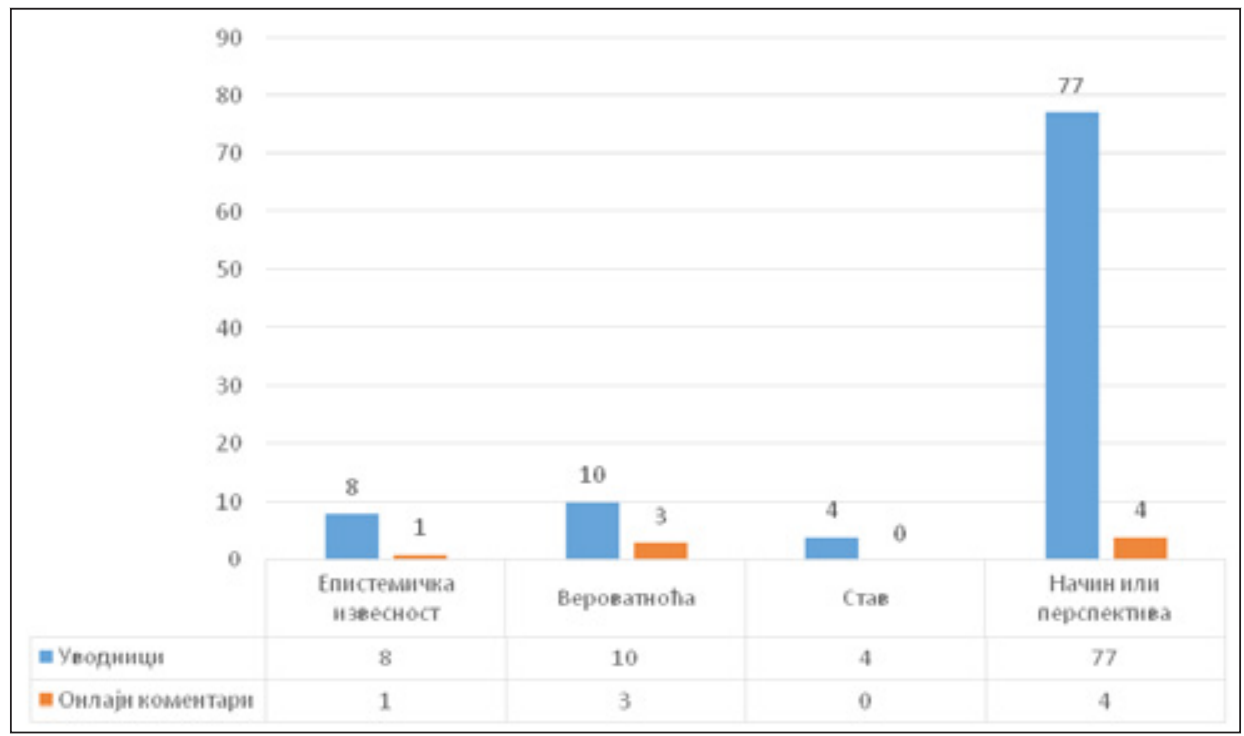

Дијаграм 2. Дистрибуција прилога у уводницима и онлајн коментарима на 10.000 речи

Прилози за изражавање начина или перспективе су најбројнији у оба регистра. С обзиром на то да постоји већи број прилога у текстовима уводника, исту тенденцију прате и прилози за исказивање начина или перспективе. Многи од датих прилога се користе да укажу на то да одређени исказ описује уобичајено стање ствари.

(22) Всё давным-давно понятно, а в Кремле тем более, потому и не было вообще никакой реакции по признанию/непризнанию на избрание Зеленского.

'Све је одавно јасно, а тим пре у Кремљу. Због тога и није било уопште никакве реакције на признавање/непризнавање избора Зеленског.' 
Што се тиче значења извесности и вероватноће, оно је, пре свега, изражено, као што смо видели, модалима са антиципаторним значењем, као и са значењем могућности и неопходности, а у много мањој мери прилозима.

Tрећу групу представљају глаголи за изражавање епистемичке извесности, вероватноће, става, говорног чина, когнитивних радњи, жеље/интенције/одлуке. Они по заступљености чине трећу групу у оквиру уводника (28,17\% анализираних облика) и другу групу (6,74\% анализираних облика) у оквиру онлајн коментара. Њихова дистрибуција по врстама је приказана у дијаграму 3 :

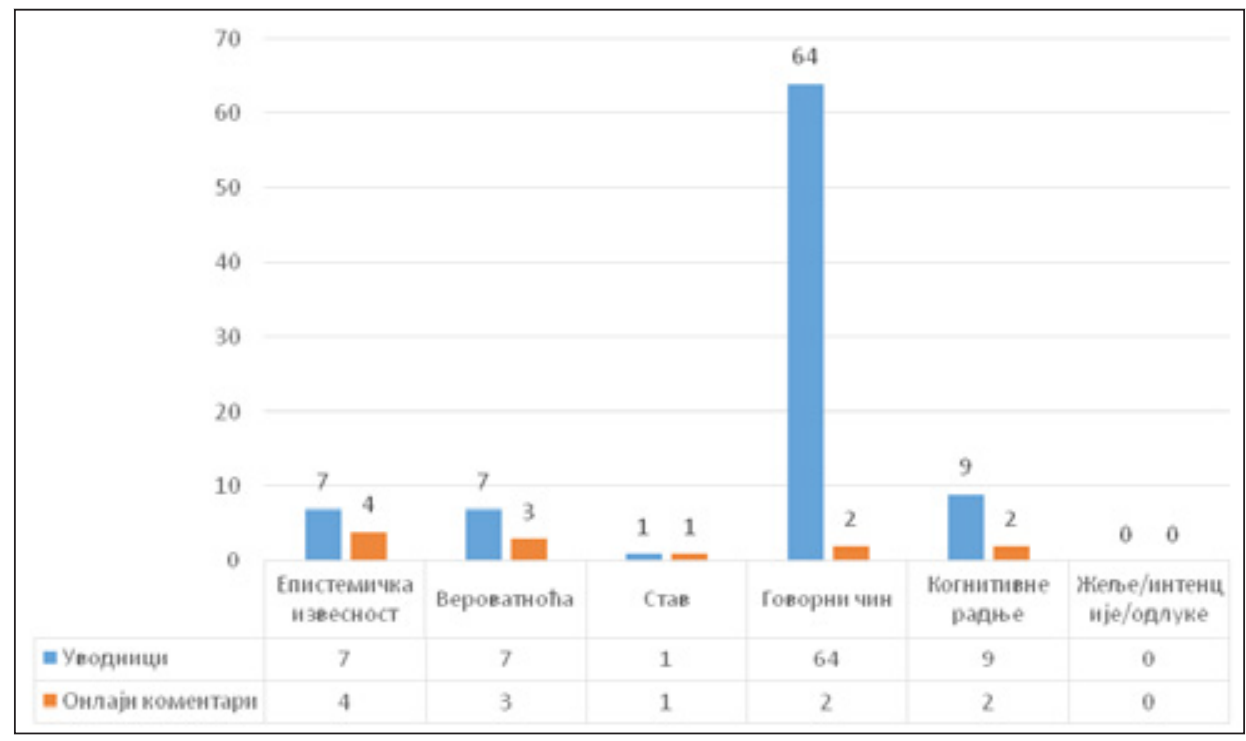

Дијаграм 3. Дистрибуција глагола у уводницима и онлајн коментарима на 10.000 речи

Дијаграм 3 приказује да су у оквиру уводника најприсутнији глаголи са значењем говорног чина, док су у онлајн коментарима најфрекветнији глаголи за изражавање епистемичке известности и вероватноће. Уводници често преносе нечије исказе, а коментари читалаца се, између осталог, баве предвиђањем догађаја, што је илустровано у примерима (23) и (24):

(23) Сторонник в данном случае - тот, кто сообщил социологам, что, пройди выборы в Думу в ближайшее время, он проголосовал бы за коммунистов («Единую Россию», ЛДПР, «Справедливую Россию»).

'Присталица је у датом случају онај који је саопштио социолозима да када би били одржани избори за Думу у кратком року, он би гласао за комунисте (,„Јдинствену Русију”, ЛДПР, „Праведну Русију”).'

(24) Да нет, думаю «дядя» убил отца ребёнка.

'Не, мислим да је „чика” убио оца детета.'

(25) Мне кажется вы ошибаетесь.

'Чини ми се да грешите.' 
Значајна је разлика у фрекветности између анализираних врста глагола у уводницима и онлајн коментарима управо због постојања релативно великог броја глагола са значењем говорног чина у уводницима. Сличност између два регистра представља одсуство глагола са значењем изражавања жеље/интенције/одлуке. Овакви глаголи се најчешће употребљавају у првом лицу, неретко исказујући индиректну директивну функцију, а садржај и уводника и онлајн коменатара вести се најчешће односи на дескрипцију неке спољне ситуације.

Четврту групу анализираних граматичких облика представљају придеви који указују на ауторску позицију. Они су најмање заступљени у оба типа текста. Па ипак, њихова фреквентност је за нијансу већа у уводницима него у онлајн коментарима (4 према 2 на 10.000 речи). Придеви који се појављују су (не)трудный 'тежак', 'лак', важный 'важан', возможный 'могућ', необходимый 'неопходан', готовый 'спреман', невероятный 'невероватан' у комбинацији са инфинитивом. Овакве конструкције оцењују најчешће пожељност/важност/могућност за остваривање неке радње или догађаја.

5. ЗАкључАк. У закључку овог рада приказаћемо дијаграм који издваја семантичке карактеристике представљене анализираним граматичким облицима (модалима, прилозима, глаголима и придевима) у уводницима и онлајн коментарима.

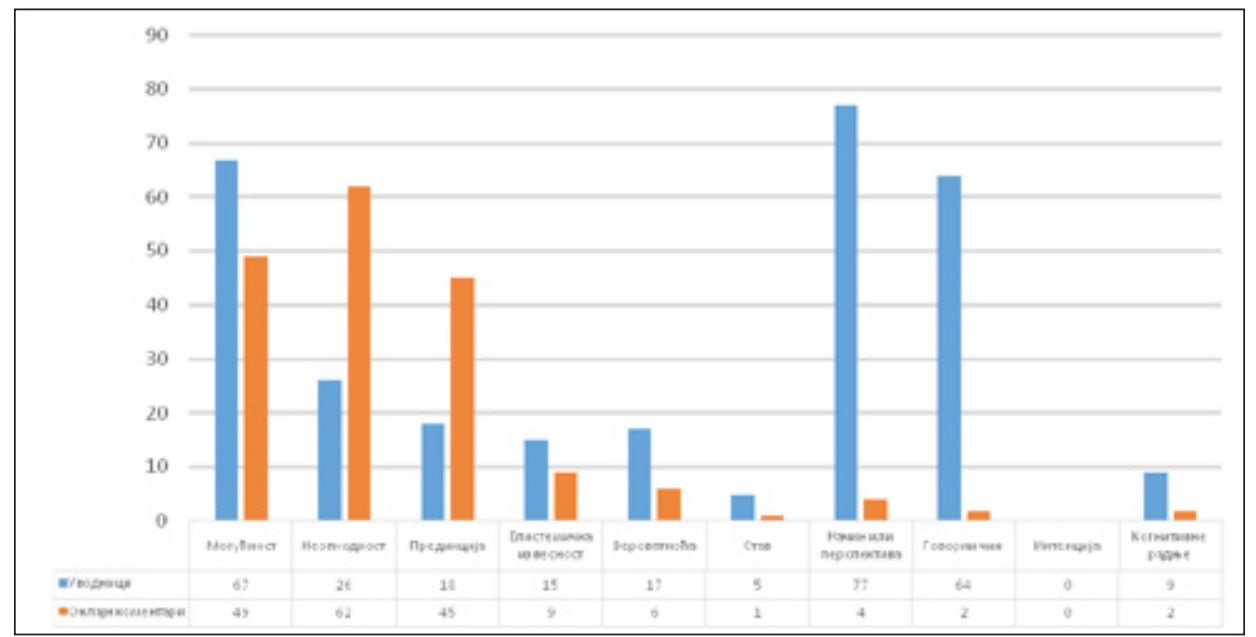

Дијаграм 4. Дистрибуција семантичких карактеристика у уводницима и онлајн коментарима (10.000 речи)

Илустровани пресек стања у односу на задате параметре показује да је фокус унутар уводника пре свега на позицији аутора којом се карактерише нека радња, а у нешто мањој мери на говорним чиновима којима се преносе туђе речи и на могућностима за реализацију нечега, док је фокус у онлајн коментарима најпре на епистемичкој (могућност и предикција) и директивној 
(неопходност) димензији ауторског става. Резултати следе из функционалних и комуникативних аспеката сваког од проучаваних регистара: уводници подразумевају субјективно изражавање позиције аутора на основу тема које се обрађују у њима, али и разговор о потенцијалима за реализацију одређених догађаја, док се кроз онлајн коментаре читаоци често баве предвиђањем будућих догађаја, у исто време дајући мање или више конструктивне предлоге како би ствари требало да изгледају и функционишу. Дата анализа на корпусу малих размера јасно илуструје везу између три елемента у тексту: језичке форме и њеног значења, ситуативног контекста у коме се регистар употребљава и функционалног односа између прва два елемента.

\section{ЦИТИРАНА ЛИТЕРАТУРА}

ДРАГићевић, Рајна. Прияеви са значењем људских особина у савременом срйском језику-йворбена и семанииичка анализа. Библиотека Јужнословенског филолога, Нова серија, књ. 18. Београд: Институт за српски језик САНУ, 2001.

Сидорова, Ирина Генадиевна. Коммуникативно-прагматические характеристики жанров персонального интернет-дискурса (сайт, блог, социальная сеть, комментарий): дис. на соискание ученой степени к-та филологических наук. Волгоград: Волгоградский государственный университет, 2014.

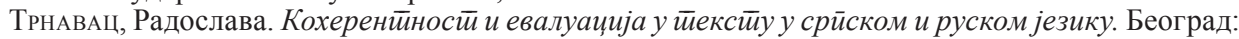
Српска академија наука и уметности, 2018.

ШАховский, Виктор Иванович. Лингвистическая теория эмоций. Москва: Гнозис, 2008.

Biber, Douglas. Stance in Spoken and Written University Registers. Journal of English for Academic Purposes 5 (2006): 97-116.

Biber, Douglas, Edward Finegan. Adverbial Stance Types in English. Discourse Processes 11/1 (1988): $1-34$.

Biber, Douglas, Edward Finegan. Styles of Stance in English: Lexical and Grammatical Marking of Evidentiality and Effect. Text 9 (1989): 93-124 (special issue on The Pragmatics of Affect, ed. by Elinor Ochs).

Biber, Douglas, Stig Johansson, Geoffrey Leech, Susan Conrad, Edward Finegan. Longman Grammar of Spoken and Written English. Harlow, Essex: Pearson Education Ltd, 1999.

Biber, Douglas, Susan Conrad. Register, Genre, and Style. Cambridge: Cambridge University Press, 2019.

Bruce, Ian. Evolving Genres in Online Domains: The Hybrid Genre of the Participatory News Article. Mehler, Alexander Sharoff, Serge, Santini, Marina (eds.). Genres on the Web: Computational Models and Empirical Studies. Dordrect - Heidelberg - London - New York: Springer, 2010, 323-348.

Chafe, Wallace, Johanna Nichols. Evidentiality: The Linguistic Coding of Epistemology. New Jersey: Ablex Norwood, 1986.

Conrad, Susan, Douglas Biber. Adverbial Marking of Stance in Speech and Writing. Susan Hunston, Geoff Thompson (eds.). Evaluation in Text: Authorial Distance and the Construction of Discourse. Oxford: Oxford University Press, 2000, 56-73.

ĐorĐević, Jasmina. The Sociocognitive Dimension of Hate Speech in Reader's Comments on Serbian News Websites. Discourse, Context \& Media 33 (2020): 1-9.

Ehret, Katarina, Maite TABOADA. Are Online News Comments like Face-to-Face Conversation? A Multi-Dimensional Analysis of an Emerging Register. Register Studies 2 (2020): 1-36.

Hunston, Susan, Thompson, Geoff. (eds.). Evaluation in Text Authorial Stance and the Construction of Discourse. Oxford: Oxford University Press, 2000.

LAnglotz, Andreas, Miriam Locher. Ways of Communicating Emotional Stance in Online Disagreements. Journal of Pragmatics 44 (2012): 1591-1606. 
Martin, J. R., P. R. R. White. The Language of Evaluation. New York: Palgrave, 2005.

O'Donnell, Michael James. Demonstration of the UAM Corpus Tool for Text and Image Annotation. Conference: ACL 2008, Proceedings of the 46th Annual Meeting of the Association for Computational Linguistics, June 15-20, 2008. Ohio: Columbus, Demo Papers.

Ochs, Elinor, Bambi Schieffelin. Language Has a Heart. Text 9 (1989): 7-25.

Taboada, Maite, Julian Brooke, Milan Tofiloski, Kimberley Voll, Manfred Stede. Lexicon-Based Methods for Sentiment Analysis. Computational Linguistics 37 (2011): 267-307.

TRnavaC, Radoslava, Maite TABOADA (рад у припреми). Epistemic Stance and Constructiveness in Online News Comments in English and Russian. Text \& Talk.

Weizman, Elda, Gonen Dori-Hacohen. Online Commenting on Opinion Editorials: A Cross-Cultural Examination of Face Work in the Washington Post (USA) and NRG (Israel). Discourse, Context \& Media 19 (2017): 39-48.

Radoslava Trnavac

\section{AUTHORIAL STANCE EXPRESSED WITH GRAMMATICAL STRUCTURES IN EDITORIALS AND ONLINE COMMENTS IN RUSSIAN}

\section{Su m m a ry}

This paper describes major patterns of register variation between editorials and online news comments based on the use of a wide range of lexico-grammatical structures that express stance in Russian. While applying the methodology of Biber (BIBER 2006), the objective of the paper is to make a distinction between the two registers that is related to the occurrence of the structures, such as modals, adverbs, verbs and adjectives with certain types of semantic meaning within a corpus of 10,000 words from each register. The results show that there are important register differences in the particular kinds of stance meanings which are expressed in editorials and online comments. The focus of editorials is on the author's perspective that characterizes certain actions or events, and to a lesser extent on speech acts and on anticipatory aspects of texts, while the focus of online comments is on the epistemic and directive dimensions of stance.

Универзитет у Београду

Филолошки факултет

Катедра за славистику

Студентски трг 3, 11000 Београд, Србија

trnavacr@gmail.com
(Примљено: 28. јула 2020;

прихваћено: 28. октобра 2020) 